\title{
NECROLÓGIO
}

\section{KENNETH EUGENE MOTT}

O Dr. Kenneth Eugene Mott faleceu no Hospital da Universidade George Washington, no dia 14 de junho próximo passado. Ken Mott nasceu em 15 de março de 1939, em Lafayette (Indiana) nos Estados Unidos. Completou o estudo ginasial em São Paulo, em 1957. Estudou medicina na Universidade Purdue e Escola de Medicina Cornell, graduando-se em 1964. Fez Residência Médica no Hospital da Universidade de Maryland, em Baltimore (1965-1966). Fez treinamento no Centro Médico do Exército norteamericano em Brook, Santo Antônio. Em 1967, veio para a Bahia, onde revalidou o diploma dos EEUU. Inicialmente, trabalhou na Fundação Gonçalo Moniz, participando de nossos estudos longitudinais em São Felipe e Caatinga do Moura. É desta data a fotografia aqui apresentada. Voltou aos Estados Unidos para fazer pós-graduação na Faculdade de Medicina de Harvard, em Boston,

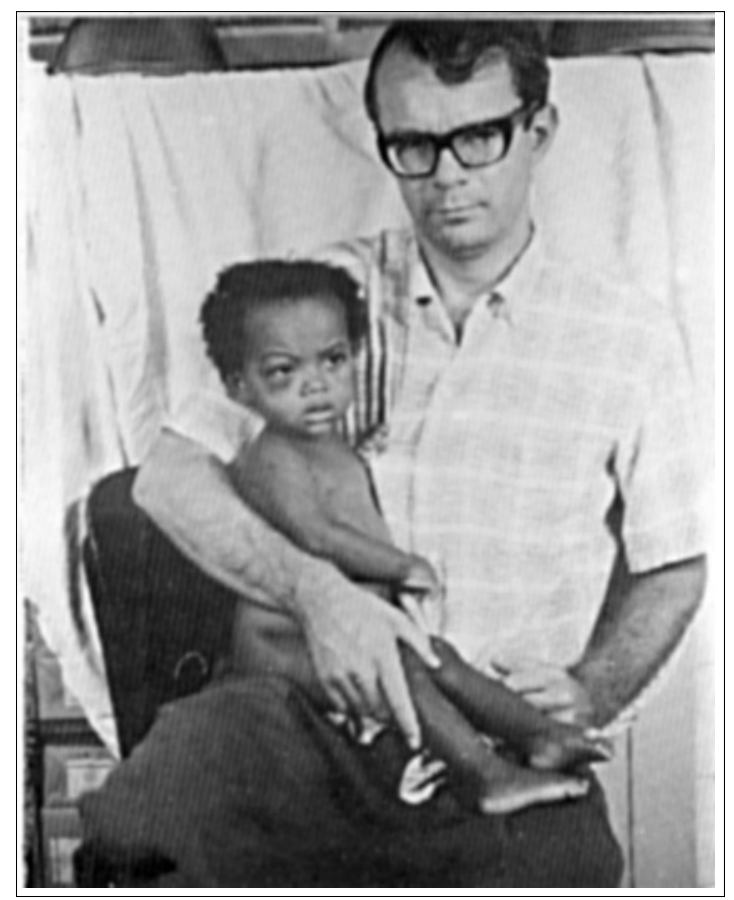

Ken Mott, em 1967, com paciente de fase aguda da doença de Chagas. com o Prof. Thomas H. Weller. Depois, como assessor da Organização Panamericana de Saúde, participou do Programa que a Escola de Medicina Tropical e Higiene de Londres, sob o patrocínio da Fundação Wellcome, realizava na Bahia, conjuntamente com a Fundação Gonçalo Moniz e a Clínica de Doenças Tropicais e Infectuosas da Faculdade de Medicina da Universidade Federal da Bahia. Na Bahia trabalhou, também, em Castro Alves. Em 1977, ingressou na Organização Mundial da Saúde, levado por A. Davis, como Secretário do Steering Committee for Schistosomiasis no TDR. Na OMS, em 1982, foi indicado como Chefe da Unidade de Esquistossomose no Programa de Doenças Parasitárias (atualmente Divisão de Controle de Doenças Tropicais), onde trabalhou até o fim de sua vida.

O interesse de Ken pelo estudo das doenças tropicais começou quando ainda era estudante, preparando com Benjamin Kean e A.G. Russel, os dois volumes da versão em inglês dos trabalhos clássicos em Medicina Tropical e Parasitologia, publicada em 1977. Na OMS, ele incentivou as pesquisas e atividades de controle de várias parasitoses, principalmente a esquistossomose. Conhecia bem os problemas de saúde dos países subdesenvolvidos e sempre lutou para atenuá-los. Dedicou sua vida ao avanço da medicina e a melhoria dos padrões de saúde. Procurava ajudar todos que dele se aproximavam e incentivou a vocação de jovens.

Publicou em colaboração com Doumenge o famoso Atlas of the Global Distribution of Schistosomiasis, em 1987. Juntamente com Chen fez três excelentes revisões sobre morbidade na esquistossomose e editou um livro sobre plantas moluscicidas. Ao todo, foram mais de oito dezenas de trabalhos principalmente sobre esquistossomose e doença de Chagas.

Na sua primeira vinda ao Brasil, acompanhava seu pai que, sob o patrocínio do Departamento de Estado dos EEUU, fazia estudos sobre capim Brachiara e outros tipos de forrageiras africanas que posteriormente foram introduzidas com muito êxito no Brasil. Depois voltou, a 
meu convite, quando o conheci na Cornell, para trabalhar na Bahia. Esta vinda ao Brasil teve muita influência em sua vida. Tinha muitos amigos* e colaboradores no Brasil. Dos seus 47 primeiros trabalhos publicados, 25 foram em associação com autores brasileiros. Sob o ponto de vista afetivo, foi na Bahia que encontrou Ingrid, com quem veio a se casar. Manifestou de várias maneiras uma simpatia especial para com o Brasil e sempre distinguia os brasileiros. De certa feita, em uma reunião em Genebra, ouvi-o dizer que a metodologia por ele adotada para os estudos longitudinais de campo sobre esquistossomose japônica estimulados pela OMS, era a que vira na Bahia.
Sua doença o impediu de receber o título de cidadão honorário de São Felipe, BA, área endêmica de doença de Chagas, onde seu trabalho comunitário nunca foi esquecido pela população.

Acometido pelo câncer, enfrentou a adversidade com estoicismo.

Sua perda é irreparável. Sempre será lembrado pelas suas qualidades pessoais e pelos benefícios que prestou aos seus semelhantes. Deixa sua esposa Ingrid, bondosa companheira de longos anos, que sempre o apoiou com total dedicação, na sua missão de eliminar doenças e de ajudar os que sofrem.

Aluizio Prata

* página 415. 